\title{
Iskolai oktatás egy vidéki társadalom szemszögéből
}

\author{
School education from the perspective of a rural society \\ BIRÓ A. ZOLTÁN, BODÓ JULIANNA
}

BIRó A. Zoltán: egyetemi tanár, Sapientia Erdélyi Magyar Tudományegyetem; 400112 Kolozsvár, Str. Matei Corvin 4.; kutató, KAM - Regionális és Antropológiai Kutatások Központja; Csíkszereda 530131, Mihail Sadoveanu 14.; birozoltan@uni.sapientia.ro; https://orcid.org/0000-0003-4562-3466

BODÓ Julianna: egyetemi tanár, Sapientia Erdélyi Magyar Tudományegyetem; 400112 Kolozsvár, Str. Matei Corvin 4.; kutató, KAM - Regionális és Antropológiai Kutatások Központja; Csíkszereda 530131, Mihail Sadoveanu 14.; bodojulianna@uni.sapientia.ro; https://orcid.org/0000-0003-0223-5164

\section{KULCSSZAVAK: vidéki iskolák; vidékfejlesztés; Székelyföld}

ABSZTRAKT: A tanulmány a csíkszeredai székhelyű KAM - Regionális és Antropológiai Kutatások Központjának munkatársai által végzett oktatási tematikájú kutatások eredményeit foglalja össze. Ezek a kutatások (családi háztartásokra irányuló kérdőíves felmérések, interjús adatfelvételek, esetelemzések, narratívaelemzések, tanulók körében végzett kutatások) a székelyföldi régióban zajlottak a románai rendszerváltást követő három évtizedben. A tanulmány áttekintést nyújt arról, hogy a kutatási eredmények milyen tapasztalatokat kínálnak a vidéki térségben működő oktatási intézmények társadalmi szerepének újrapozicionálása szempontjából. A rurális oktatási intézmények újrapozicionálásának kérdése hangsúlyosan előtérbe került az utóbbi időszakban, s ez összefügg a vidéki térségek fölértékelődésével. A szerzők szerint e probléma szakmai tematizálása a székelyföldi térségben is aktuális lehet. A tanulmány fölvázolja azokat a társadalomtörténeti előzményeket, amelyek az 1989-es romániai társadalmi változás után hatottak az iskolai oktatáshoz való viszonyulás alakulására, ezt követően bemutatja az iskolai oktatáshoz való viszonyulás 1989 utáni alakulásának és mai helyzetének fontosabb jellemzőit. A tanulmány az iskolai oktatás kérdéskörével nem kisebbségpolitikai megközelítésben, hanem vidékkutatási témaként foglalkozik.

A szerzők következtése szerint a vizsgált térségben is célszerủ nagyobb teret adni a vidékkutatáshoz kapcsolódó olyan elemzéseknek és szakmai értelmezéseknek, amelyek az oktatóintézmények szerepét, illetve az iskolák és társadalom kapcsolatát a térségi társadalom működésének jellemzői felől közelítik meg. Székelyföldön időről időre fölmerül az a kérdés, hogy a térség saját erőforrásaira alapozva (önkormányzatok, közbirtokosságok, vállalkozások) tehet-e valamit saját oktatási intézményeinek érdekében. Az egyik válasz erre a kérdésre az oktatási intézmények társadalmi szerepváltása lehet. A tanulmány ehhez kínál szakmai kiindulópontokat.

Zoltán BIRÓ A.: professor, Sapientia Hungarian University of Transylvania; Str. Matei Corvin 4., 400112 Cluj-Napoca, Romania; researcher, WAC - Center for Regional and Anthropological Research; Mihail Sadoveanu 14., 530131 Miercurea-Ciuc, Romania; birozoltan@uni.sapientia.ro; https://orcid.org/0000-0003-4562-3466

Julianna BODó: professor, Sapientia Hungarian University of Transylvania; Str. Matei Corvin 4., 400112 Cluj-Napoca, Romania; researcher, WAC - Center for Regional and Anthropological Research; Mihail Sadoveanu 14., 530131 Miercurea-Ciuc, Romania; bodojulianna@uni.sapientia.ro; https:// orcid.org/0000-0003-0223-5164

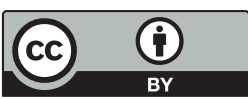


KEYWORDS: rural schools; rural development; Szeklerland

ABSTRACT: The study summarizes the results of a research project on education conducted within the framework of the WAC - Center for Regional and Anthropological Research in Miercurea Ciuc (Harghita County, Romania). The research that used qualitative methods (questionnaire on family households, interview data collection among teachers and parents, case studies, narrative analysis), took place in the Szeklerland region of Romania during the three decades following the regime change. The study reviews and summarizes research results with a view to lessons about repositioning the social role of education institutions operating in rural areas. The repositioning of rural education has gained special attention in academic research in recent years. The study outlines the socio-historical antecedents that influenced the development of attitudes towards school education after the regime change in Romania in 1989. It then presents the main features of the change in attitudes towards school education after 1989 and its current situation. The study deals with the issue of school education from the perspective of rural studies rather than minority politics.

Our findings suggest that the role of education institutions and the relationship between schools and local society should be given more space in academic research. Policy relevance can be seen in the way the development of rural institutions is not a priority for national educational development. Pilot programs supporting innovation in education in Romania take place in nonrural areas, decisions related to the maintenance of individual schools (for example merging of institutions and classes) are based primarily on economic and financial considerations, and investments are rehabilitative in nature and serve to maintain existing levels of actual activities. In the Szeklerland region, the question arises from time to time whether the region can do something for its own education institutions relying on its own resources (for example municipalities and other local institutions, enterprises, non-governmental organizations)? One important answer to this question may be the change in the social role of education institutions, which is a multifactorial issue. The study offers starting points for outlining the conditions for the changing role of rural schools in local societies.

\section{Bevezetés}

A csíkszeredai székhelyű KAM - Regionális és Antropológiai Kutatások Központja munkájában a vidékfejlesztés lehetőségeinek (és korlátainak) elemzése az 1990-es években, a magyarországi vidékkutatókkal való együttműködés nyomán kapott teret. G. Fekete Éva vidékkutatóként és térségfejlesztő szakemberként meghatározó szerepet vállalt abban az egyéves székelyföldi képzési programban, amelynek eredményeként 18 kistérség szerveződött a térségben, és elindult a kistérségi menedzserek képzése is. Csíkszeredai előadásai, illetve tanulmányai (G. Fekete 1999, 2001) révén ismertük meg a bottom-up típusú fejlesztéspolitika szemléletét és gyakorlatát, a későbbi együttműködési programok keretében pedig a területfejlesztésben mutatkozó paradigmaváltás nemzetközi szakirodalmi anyagait (G. Fekete 2008). Kutatásainak, tanulmányainak, előadásainak szakmai üzenete (az alap- és az alkalmazott kutatás kapcsolata, az interdiszciplináris megközelítés hasznossága, a nemzetközi szakirodalom ismeretének fontossága, a hátrányok mellett az esélyek feltárása) együttműködésünk első pillanatától kezdve ösztönző erejű volt számunkra. A vidéki társadalom működési mintázatainak feltárása, megértése, figyelembe vétele nélkül mind a top-down szemléletủ támogatáspolitika, mind a bottom-up típusú, en- 
dogén forrásokra alapozó fejlesztéspolitika csak részleges eredményeket érhet el. Kutatási témáink körében a térségi oktatás működése volt az egyik olyan fontos terület, ahol az elmúlt három évtized során folyamatosan törekedtünk a vidékkutatás holisztikus szempontjainak érvényesítésére.

Meghatározza-e napjainkban lényeges módon a vidéki társadalom jellege az adott térségben található oktatási intézmények működésmódját? Ha a vidéket a periferikus térséggel azonosítjuk - és a társadalmi-gazdasági mutatószámok alapján az ilyen definíció az általunk vizsgált régióban nem is meglepő -, akkor az értelmezés és a fejlesztési javaslatok kialakítása jól ismert modellt követ. E modell szerint az urbánus térségekhez viszonyítva a vidéki települések a kisebb intézmények, az alacsony tanulólétszám, a fejlesztésre váró infrastruktúra, a gyengébb eszközellátottság, az alacsonyabb képzettségű pedagógusok, az iskolai oktatás szempontjánól kedvezőtlenebb családi háttér mutatószámai alapján, a "hátrányos helyzetü" térség fogalmához jutunk, és nem kérdéses az ilyen térségben müködő oktatás kedvezőtlen társadalmi meghatározottsága.

De mi a helyzet abban az esetben, ha a hátrányos helyzet statisztikai mutatószámai valóságosak ugyan, de a szóban forgó térség nem tekinti magát periferikus helyzetűnek? Ha a vidékiség egyéb adottságait (társadalmi szerkezet, életvezetési modellek) a térségben élők pozitívumnak tekintik, kisebb-nagyobb körben sajátnak érzett/tudott társadalmi nyilánosságot működtetnek, a térség egyes részeire és egészére vonatkoztatott identitásokkal bírnak (és építik is azokat)? Nem utolsósorban pedig, ha ez a térségi társadalom a nyelvi és etnikai különbözőség okán az országos rendszerrel szemben (az adminisztratív apparátustól a nemzeti ideológiáig terjedő skálán, mentális és gyakorlati síkon egyaránt) oppozíciós mintákat alakít ki és múködtet? Erre a helyzetre példa a romániai székelyföldi térség, amelynek oktatási hálózata jogi-adminisztratív értelemben az országos hálózat része, fenntartója az állam, amely centralizált rendszert müködtetve írja elő az oktatás tartalmát és gyakorlatát. Ugyanakkor a székelyföldi társadalom a térségi oktatást intézményeivel, személyzetével, tevékenységével és társadalmi szerepével egyetemben - implicit vagy explicit módon - "sajátnak" is tekinti. Tanulmányunkban azt a kérdést vizsgáljuk, hogy milyen módon befolyásolják a Székelyföld jellemzői a térségi magyar oktatás működését. Az oktatás témaköréből az intézmények működését, a pedagógusi szerepek, illetve az oktatási/tanulási tevékenység térségi társadalmi szerepének alakulását elemző kutatási edeményeket mutatjuk be.

Megközelítésünk eltér a romániai magyar, ezen belül a székelyföldi oktatásüggyel foglalkozó - normatív jellegű - romániai magyar kisebbségpolitikai diskurzustól és kutatási gyakorlattól. Normatív jelleg alatt azt értjük, hogy az oktatással kapcsolatos szakmai, szakpolitikai és hétköznapi diskurzusok, témák döntő hányadát a magyar közösség kisebbségi helyzetéből adódó hátrányok és igények, az ezekhez kapcsolódó érdekérvényesítési elképzelések és törekvések határozzák meg. A kisebbségi magyar oktatás (a kisebbségi diskurzusban metafo- 
rája: „az Iskola”) problémaköre három évtizede a kisebbségpolitikai diskurzus legfontosabb toposzai közé tartozik a székelyföldi térségben is. A beszédmódot és az iskola témakörével kapcsolatos magatartási modelleket egyaránt meghatározó fontosabb témaköröknek két nagy csoportja van. Az egyik az állammal szembeni követelések, elvárások (oktatási intézmények visszaigénylése, intézmények, oktatói állások, beiskolázási keretszámok, tankönyvek igénylése) körül formálódik, a másikat az iskolahálózat leépülése vagy a leépülés veszélye (tanulólétszám és oktatói állások csökkenése, osztályok összevonása, a teljesítménymutatók romlása országos összehasonlításban) alkotja. A politika, a média, a szakpolitikai és intézményi diskurzus együttesen tartja fenn ezt a tematizációt, amelynek része a szakmai-szakpolitikai diskurzus, illetve az iskolaügyhöz kapcsolódó szimbolikus eseményeket kísérő narratívák halmaza. Ebben a kontextusban a térségi oktatással (és a romániai magyar oktatás egészével) foglalkozó felmérések és elemzések döntő hányada olyan témákat helyez előtérbe, mint a magyar nyelven tanulók létszámának alakulása, a beiskolázási mutatók évenkénti változása, a pedagógusok létszámának alakulása, a magyar nyelvű tankönyvellátottság helyzete, az oktatás régiók és településtípusok szerinti veszélyeztetettsége; ennek újabb összegző megfogalmazását lásd az „Iskolák veszélyben” című kiadványban (Barna et al. 2016). A közéleti és szakpolitikai diskurzusban is ezek a témák kapnak nagyobb hangsúlyt.

Jóval kevésbé jellemző az olyan szakmai megközelítés, amely az intézmények működési módjával, a pedagógusok helyzetével, az oktatás társadalmi szerepével, illetve általában az oktatás és a térségi társadalom kapcsolatával foglalkozik. Fontos kivételnek tekinthető Mandel Kinga (2016) könyve, meg kell azonban jegyezni, hogy a kutató Magyarországon dolgozik, és a kiadvány is ott jelent meg. Általában elmondható, hogy a térségre jellemző közéleti és szakpolitikai iskolanarratíva az adatokhoz és a folyamatokhoz ideologikus és szimbolikus tartalmakat társít, és szerkezetében oppozíciós jellegű (mi - ők, kisebbség - többség, kisebbség - állam, magyar - román, magyar - anyaországi magyar), és az ellentétpár „saját” oldala hordozza a pozitív tartalmakat. Normatív jellegét nem csupán az ideologikus tartalom biztosítja, hanem a fontos témák és témakezelési módok jól definiálható köre is (milyenek voltunk, mi hiányzik, melyek a mai adatok, mi épül le, mit nem ad a hatalom, milyen gondjaink vannak, mit értünk el, mit akarunk, mire van szükségünk), és nem utolsósorban a számok dominanciája az értelmezések felett. A témakezelés affirmatív, nem kevés esetben kifejezetten definíciójellegü. A normatív diskurzus szimbolikus és ideologikus súlya azt eredményezi, hogy ez a beszédmód uralja és képviseli a térségi oktatás problémakörét. A narratíva domináns témáitól és témakezelési módjaitól nyilván el lehet térni, de az eltérő témák és beszédmódok rendszerint az iskolanarratíván kívülre szorulnak. Ez a térségi társadalmi adottság a helyzetfeltáró munkának vagy a résztémák elemzésének nem kedvez, azok másodlagos szerepet kapnak, zavaró vagy felesleges tényezőként jelennek meg. 


\section{Túl a normatív megközelítésen}

A kisebbségpolitikai narratívában megjelenített statiszikai tények és változási folyamatok (az oktatás intézményi kereteinek trendszerü csökkenése) valóságosak. Ez azonban a térségi oktatás működésének csupán az egyik részét jelenti. Már az oktatás működésével kapcsolatos hétköznapi társadalmi tematizáció is nagyságrendekkel gazdagabb, mint a normatív beszédmód. A normatív megközelítést kibővítő helyzetelemzés, illetve a fejlesztéspolitikai megközelítés tovább bővíti a térségi oktatással kapcsolatos témákat. A vidékkutatás szempontjai és módszerei a normatív megközelítésnél jóval szélesebb kontextusba helyezik a térségi oktatást, szakmai szempontokat kínálnak a kialakult helyzet holisztikusabb megközelítéséhez, illetve fejlesztéspolitikai megoldásokhoz. Az alábbiakban két olyan szélesebb körű változási folyamatra szeretnénk jelzésszerüen utalni, amelyek külső tényezőként - a térségi oktatáshoz kapcsolható helyzetelemzési és fejlesztéspolitikai tematizáció kialakításának szükségessége mellett szólnak. Az első az új vidékfejlesztési paradigma előtérbe kerülése (többszintű kormányzás, a vidéki térségek fölértékelődése, endogén értékek előtérbe helyezése, fenntarthatóság, bottom-up típusú fejlesztési modellek), ennek a paradigmaváltásnak a hatása részben már az általunk vizsgált térségben is kimutatható. A második a vidéki iskolák újrapozicionálásához kapcsolódó kezdeményezések térnyerése. $\mathrm{E}$ két kérdéskör rendszeres és részletes térségi szakmai-közéleti tematizációja szükségesnek mutatkozik ahhoz, hogy a székelyföldi térség oktatási folyamatainak értelmezésében túl lehessen lépni a ma domináns normatív megközelítésen.

\section{Elötérben a vidék}

A helyi fejlesztés, az agrárinnováció, a lokális identitás témakörében végzett térségi kutatássorozataink (Biró, Magyar 2017; Bodó 2019; Biró, Laczkó-Albert, Sárosi-Blága 2019) eredményei egyértelműen jelzik, hogy Székelyföldön is fokozatosan előtérbe kerülnek az „új vidékfejlesztési paradigma” (OECD 2006) szempontjai és gyakorlatai. Erre utal többek között az, hogy egyre nagyobb teret nyer a falusi települések multifunkcionális jellege, a településeken az agrártermelés mellett megjelenik a rendezvényszervezés és a turizmus, bővülnek a lokális identitás erősítését célzó törekvések, megjelennek a nem agrárjellegű vállalkozások, a külső forrásbevonásra alapozó fejlesztések mellett pedig fokozatosan egyre nagyobb szerepet kapnak a bottom-up típusú helyi kezdeményezések és az endogén erőforrások bevonása iránti igény (Biró 2016). Az utóbbi két évtized nemzetközi vidékkutatásai sokféle területen jelzik a rurális terek funkcióváltását. Van der Ploeg és szerzőtársai (2000) a vidéki térség újradefiniálásának öt jellemzőjét veszik számba, Michael Woods (2007) a globalizációs hatások kapcsán szintén öt témakörben vizsgálja a vidéki térségek átalakulását. De ide sorolhatunk olyan további elemzéseket is, melyek tárgya például a poszt-produktivizmus térnyerése a gyakorlatban 
és a közpolitikai diskurzusban (Almstedt et al. 2014), a rekreáció és a fogyasztási gyakorlat átalakulása (Lundmark 2006; Mather, Hill, Nijnik 2006). Almstedt és szerzőtársai (2014) azt is kiemelik, hogy az új vidékfejlesztési paradigma által jelzett fordulat nem csupán az agráriumot, hanem a vidéki életvezetés jóval több szintjét érinti. Ennek a fordulatnak fontos összetevője a kulturális markerek szerepének elötérbe kerülése (Ray 1998), a rurális elitek szerepének átalakulása (Gray, Sinclair 2005), a helyhez való viszonyulás változása (Chesire, Meurk, Woods 2013), a kreatív osztály rurális térségben való megjelenése (Herslund 2012). Székelyföldön is több jel mutat a rurális terek újraértékelődésére. Többek között erősödik a városról falura költözés folyamata, előtérbe kerül a lokális identitás építésének témaköre, a helymarketing fontossága, szembetűnő az egyéni életvezetés holisztikus jellegének visszaállítására irányuló törekvések sokszínüsége, erősödik az erdő- és a környezetgazdálkodás szerepe, egyre fontosabb a társadalmi részvétel kérdésköre, és a térségre korábban nem jellemző agrárinnovációs kezdeményezések jelennek meg. Ez a gyakorlati és szemléleti fordulat ma már megjelenik a térségi fejlesztéspolitikai tematizációkban (szakpolitikai anyagok, médiaanyagok) és programokban is, elsősorban olyan témakörök kapcsán, mint a helyi értékek hasznosítása, a lokális identitás, a turizmus, a rendezvényszervezés. A vidéki térség fölértékelődésének a folyamata véleményünk szerint olyan változás, amely hatással lehet az életvezetés más területeire, de a helyi intézmények (többek között az iskolák) működésének újrapozicionálására is.

\section{Vidéki iskolák új szerepben}

Napjainkban a rurális iskolák újrapozicionálásának kérdése több országban, sok térségben napirenden van. A szakirodalomban sokféle szemszögből foglalkoznak a kérdéssel. Kiemelik az iskola közösségfejlesztő szerepének elemzését (McCracken, Miller 1988; Miller, Bruce 1995), a hely, a vidéki oktatás, valamint a pedagógusok szakmai identitása közötti összefüggések fontosságát (Roberts 2013). Foglalkoznak az adott intézmény társadalmi és környezeti kontextusának szerepével (Bæck 2015), a vidéki iskolák társadalmi és gazdasági jelentőségével (Lyson 2002). Mások az iskolavezetők szerepét vizsgálják (Wallin, Newton 2014; Lingam, Lingam, Raghuwaiya 2014; Bauch 2001), hangsúlyozzák a szereplők közötti hálózatosodás és párbeszéd fontosságát (Corbett, Helmer 2017), s nem utolsósorban pedig arra hívják fel a figyelmet, hogy a pedagógusok kisebb közösségekben betöltött szerepének vidékfejlesztési jelentősége is van (McCracken, Miller 1988; Miller, Bruce 1995; Williams 2010). (A szakirodalmi anyagok szemléző jellegű áttekintését lásd: Biró, Sárosi-Blága 2018).

A szakirodalmi anyagokban az „újrapozicionálás” kifejezés tartalma meglehetősen összetett, és jóval túlmutat az iskolák térségünkben ismert és megszokott oktatási-nevelési szerepkörén. Az újrapozicionálás új funkciókat, új lokális társadalmi szerepeket javasol az iskolának, és ez az oktatási intézmények múködési 
modelljének, társadalmi szerepkörének átalakulásához vezet. Az újrapozicionálás eredményeként lényeges mértékben átalakul az iskola mint helyi intézmény müködési modellje és társadalmi funkciója. Az újrapozicionálás egész sor intézményi, adminisztratív, szabályozási és személyi feltétel megváltozását igényli, kivitelezése idő- és költségigényes, valamint több szereplő együttműködését igényli. Mindebben fontos szerepe van a technológiai innovációnak (digitális eszközök, tartalmak és platformok, hálózatok), amelyek ma már periferikus helyzetü településeken is hasznosíthatók. Célszerü hangsúlyozni azt is, hogy a vidéki iskolák újrapozicionálása nem csupán kényszerűség lehet, hanem - a vidéki térségek és települések fölértékelődési folyamatához kapcsolódva - helyi fejlesztési modell, esély, versenyképességi tényező is.

Úgy véljük, hogy a fentiekben röviden jelzett két folyamathoz kapcsolódó szakmai anyagok alapján meggyőzően lehet érvelni amellett, hogy a térségi oktatás kutatásában - a normatív megközelítések kisebbségpolitikai érdekből való fenntartása mellett - célszerü teret adni a vidékkutatáshoz kapcsolódó olyan megközelítéseknek és elemzéseknek is, amelyek a térségi társadalom működésének, hatásának feltárására irányulnak. Ez térségi szempontból már csak azért is indokolt lehet, mert az országos oktatásfejlesztés számára a vidéki térségek fejlesztése napjainkban nem jelent prioritást. Az oktatási innovációt támogató pilotprogramok nem vidéki térségekben zajlanak, az egyes iskolák fenntartásával kapcsolatos döntéseket (intézmények, osztályok össszevonása) gazdasági-pénzügyi érvek alapozzák meg, a beruházások rehabilitációs jellegűek, vagy legfejlebb a szinten tartást szolgálják. Ezen tapasztalatok alapján Székelyföldön időről időre fölmerül az a kérdés, hogy a térség saját erőforrásaira alapozva (önkormányzatok, közbirtokosságok, vállalkozások) mit lehetne tenni a térségi oktatás érdekében. Ám legyen szó akár a térségi erőforrások hasznosításának mérlegeléséről, akár országos léptékű fejlesztési elképzelések gyakorlatba ültetéséről, a vidéki társadalom működésének jellegét és hatását (legyen az támogató vagy korlátozó jellegü) aligha érdemes megkerülni.

\section{Vidék és oktatás: társadalomtörténeti előzmények}

Az iskola és az oktatás kérdéskörével az Intézet 1990-ben történt hivatalos bejegyzését megelőzően kezdtünk foglalkozni, ebben az időszakban a hátrányos nyelvi helyzetről készült kiadvány (Biró 1984), illetve egy tanulmánykötetet adtunk ki a középiskolások körében végzett kutatásokról (Rostás 1989). Az 1989-es romániai rendszerváltást követően interjúsorozatok, kérdőíves adatfelvételek, esetelemzések, társadalomtörténeti kutatások keretében gyakorlatilag folyamatosan foglalkoztunk a térségi oktatás jellemzőivel regionális, táji és lokális léptékben egyaránt. Fontosabb elemzési témáink a következők voltak: az iskolához és a tanuláshoz való viszonyulás mintázatai, intézményvezetői és lakossági narratívák 
elemzése, a pályaválasztás családi meghatározottsága, funkcionális analfabetizmus, a lokális léptékủ decentralizációs folyamat, a pedagógusok szerepkonstrukciói, agrárszaklíceumok és társadalmi környezetük viszonya (Biró et al. 1994; Bodó 2004; Túros 2005, 2006; Biró, Ozsváth-Berényi 2010; Biró, Bodó, Burus-Siklódi 2015; Biró, Bodó 2016). (A témával kapcsolatos kutatásokról és publikációkról szakmai összefoglaló és szakirodalmi jegyzék készült.) $)^{1}$ Az elemzések egyik fontos tapasztalata az, hogy a székelyföldi vidéki társadalomnak az iskolához, a tanuláshoz való mai viszonyulása jelentős mértékben kötődik a társadalomtörténeti előzményekhez, és ezekkel összefüggésben a kulturális mintákhoz, közösségi meghatározottságú magatartásmodellekhez.

A térség paraszti társadalmában - egészen az 1962-ben záruló kollektivizálásig - meghatározó volt az életvezetés számára fontos „helyi/saját tudás”, és az iskola, a pedagógus által képviselt „idegen tudás” közti aszimmetrikus viszony. A helyi tudás értelmezési és értékelési keretként müködött az iskola által képviselt tudás vonatkozásában, a helyi tudás szempont- és értékrendszere határozta meg, hogy az iskolai tanulás mire való. Az 1960-as évek elejétől-közepétől fokozatosan megerősödött egy olyan folyamat, amelyben az iskolai tanulás a helyi társadalomból való kilépés csatornájaként működött (szakiskolai képzés, középiskolai képzés, később az egyetemi képzés), és a helyi tudás tudomásul is vette az iskolai tanulásnak ezt a funkcióját, domináns értelmező és értékelő funkciója ennek ellenére továbbra is megmaradt. A középfokú képzés tömegessé válása a falu szemében nem tette legitimebbé a külső tudást, a „saját” és az „idegen” tudás közti különbség ebben az időszakban is megmaradt. A középfokú képzést biztosító iskola inkább az érettségi oklevél megszerzésének helye. A tudás képviselőinek társadalmi súlya a vidéki térségben továbbra is alacsony maradt abban az értelemben, hogy a helyi társadalom az iskolai tanulás révén szerzett pozíciót (helyi pedagógus, gyógyszerész, orvos, hivatalnok) elfogadja, ám a pozícióhoz kapcsolt tudást nem tekinti a helyi tudás részének. Sőt, a vidéki életforma 1989 utáni rehabilitációja (a kollektivizálás előtti földtulajdonszerkezet visszaállítása, az 1950-es évek elején fölszámolt helyi közösségi intézmények újraindítása, erőteljes lokális identitásépítési folyamatok), a térségi munkaerőpiac teljes átrendeződése és a munkamigráció fölértékelődése még föl is erősítette az aszimmetrikus viszonyt, és - paradox módon - az iskola és a tanulás presztízsének csökkenéséhez vezetett. Nem változtatta meg lényeges mértékben ezt az alapviszonyt az egyetemi oktatás expanziója sem, ugyanis a helyi tudás értelmező és értékelő szerepe ma is többféle formában érhető tetten az iskolához és a tanuláshoz való viszonyulásban, az iskolai tanulás családi tervezésében és támogatásában, a pedagógusokhoz való viszonyulásban, vagy az iskolák által kezdeményezett programokon való részvételben. Nem mutat határozott jel arra, hogy a térséget is érintő globalizációs trendek (mobilitási lehetőségek, kommunikáció, digitalizáció, munkamigráció) ezt a viszonyulásmódot érdemben befolyásolták volna. 
Az Intézetben folytatott kutatások eredményei, a tereptapasztalatok azt mutatják, hogy a székelyföldi iskolahálózatban és oktatási/nevelési gyakorlatban az 1989 utáni három évtizedben tartósan és dominánsan jelen vannak az alábbi trendek:

- A szakmai, szakpolitikai és közéleti diskurzusban tartósan az intézményrendszer számszerüsített működési paraméterei képezik a fontos témát, ehhez képest az oktatási gyakorlat problémaköre, az oktatás minőségével kapcsolatos kérdések csoportja, a versenyképesség, a minőség, a társadalmi elvárásoknak való megfelelés mértéke és a társadalmi beágyazottság helyzete csak alkalmilag tematizálódik.

- A térség lakosságát továbbra is az alulképzettség jellemzi.

- Az egyszakos képzés gyakorlata, pozitív megítélése annak ellenére tartósnak bizonyul, hogy az 1989 utáni munkaerőpiaci változásokkal előtérbe került a szakmaváltás igénye, illetve lehetősége. Még mindig meghatározó súllyal van jelen az a meggyőződés, hogy „,egy szakmát megtanultam, és az legyen elég”. Nem zárják ki az új ismeretek szerzésének szükségességét, de azokat sokkal inkább gyakorlat, és nem iskolarendszerü képzés révén próbálják megszerezni. Az egyszakosság elve nagy szerepet játszik abban is, ahogyan a szülők befolyásolják gyerekeik iskolaválasztását (középiskolai szakok, egyetemi szakok választása). A családok nem kompetenciacsomagokban, nem tanulási tartalmakban gondolkodnak, hanem a szakok neveiben, abban bízva, hogy a tartalmas egyszakos képzés elősegíti a munkahelyszerzést.

- A szülők a tanulási életpálya tervezésében és szervezésében két domináns modellt követnek. Az egyik szerint a gyerek menjen végig minden lehetséges képzési fokozaton, míg a másik szerint a gyerek tanuljon, de amint lehet, ki kell lépnie az oktatási rendszerből. Ezek a beállítódások korán kialakulnak, menet közben rendszerint nem változnak, a szülők tanuláshoz való viszonyulásukat - nagyon kevés kivételtől eltekintve - nem a gyerekek iskolai teljesítményéből vezetik le.

- Tapasztalataink szerint több mint másfél évtizede erősödik a tanulástól (iskolától) való elfordulás trendje.

- Az oktatás és az iskola társadalmi szerepével kapcsolatban több, egymástól független narratíva alakult ki. A társadalmi nyilvánosságban a normatív narratíva dominál, míg a hétköznapi kommunikációban a beállítódásokat igazoló narratíva. A változást jelző vagy igénylő narratívák (tudástársadalom, szakmai képzés) csak hívószavakként, metaforákként, alkalmi jelleggel vannak jelen. 


\section{Vidék és oktatás: mai helyzetkép}

2019-ben intézeti kutatási program keretében (interjúk, esetelemzések) foglalkoztunk azzal a kérdéssel, hogy a vidéki térségek fölértékelődésének kontextusában milyen tényezőkkel kellene számolni abban az esetben, ha napirendre kerülne a vidéki iskolák újrapozicionálásának tervezése. E munka keretében vizsgáltuk a vidéki társadalom azon jellemzőit, amelyek az iskolák működését, a pedagógusi és az intézményvezetői szerepek alakulását napjainkban is befolyásolják. Ez a szakmai program lehetőséget és kihívást jelentett abban a tekintetben, hogy feldolgozzuk és összefoglaljuk az Intézetnek a térségi oktatással kapcsolatos több mint három évtizedes kutatási eredményeit. A következőkben ezeket a tapasztalatokat foglaljuk össze jelzésszerűen, elsősorban a székelyföldi vidéki iskolák újrapozicionálási esélye szemszögéből. Hangsúlyozzuk, hogy az alábbi összefoglaló az intézeti kutatások szakmai következtetéseit tükrözi, a térséggel foglalkozó kutatási eredmények teljes körü áttekintése jóval nagyobb feladat.

Az elemzett székelyföldi vidéki térségben az iskola és a helyi társadalmi környezet rendszeres, partnerszintü együttmüködésének nincsen kialakult gyakorlata. Ez nem jelenti azt, hogy a helyi társadalom és az iskola kapcsolata ne lenne sürü és jelentésekkel, értékkel terhelt. A helyi társadalom részéről a viszonyulás folyamatos (magatartások, vélemények, társadalmi elvárások formájában), a mai helyzetben ezt a viszonyulást az iskola mint intézmény, és a pedagógus mint személy kisebb vagy nagyobb mértékben tudomásul veheti, vagy figyelmen kívül hagyhatja (ez utóbbira az ingázó pedagógus szolgáltathat példát).

A helyi társadalom meggyőződése - miközben magatartások, vélemények és elvárások formájában értelmezési és értékelési rácsot vetít az iskola müködésére - az, hogy az iskola müködtetése nem a lokális társadalom ügye (feladata), hanem teljes mértékben az állam terrénuma és felelőssége, következésképpen ebben a lokális társadalomnak beleszólási, szerepvállalási lehetősége érdemben nincs. Ebben a meggyőződésben osztozik - nem egyforma módon, nem azonos érvekkel - három fontos helyi szereplőcsoport: a családok, a helyi elitek és a pedagógusok. Az elmúlt három évtized során több kísérlet is történt az együttmüködési keretek formalizálásra (országos léptékü decentralizációs kezdeményezések), a helyzet azonban változatlan maradt.

A helyi társadalom lokális szerepet rendel minden pedagógushoz. Ennek a szerepnek két komponense van. Az egyik egy ún. viselkedési elvárás (öltözet, magatartás, beszédmód), a másik pedig egyfajta társadalmi igény arra vonatkozóan, hogy oktatói munkája mellett tegyen valamit a helyi közösség érdekében (kulturális műsort állít össze, színdarabot tanít, tánccsoportot vezet, sportági csapatot szervez). Az ilyen jellegű elvárás azonban napjainkban mérsékődött. A szerepvállalás elmaradása esetén a szankcionálás a helyi informális értékelésben jelenik meg (megszólás, leértékelés). 
Az iskola lokális társadalmi szerepével kapcsolatos társadalmi elvárások szinte kizárólagosan az oktatási és nevelési funkcióra korlátozódnak. Ennek az elvárásnak két szintje van. Az egyik elvi és közösségi jellegü, és meg is fogalmazódik: ,az iskola/a tanár feladata az, hogy a gyerekeket oktassa és nevelje”. Az általános kijelentés mögött azonban partikuláris elvárás van: ,az én gyerekemet oktassa és nevelje jól az iskola/a tanár". A partikuláris érdek folyománya az, hogy vidéki környezetben ahány család, annyiféleképpen viszonyul az iskolához. A család a saját érdekei és értékei mentén perszonifikálja (antropomorfizálja) az iskolát mint intézményt és az oktatást mint intézményesitett gyakorlatot. A kapcsolat partikuláris jellege korlátozza a szülői bevonódás közösségi mintáinak kialakulását, ugyanakkor veszélyként értelmez minden olyan változást (a fejlesztést is), amely a már kialakított partikuláris kapcsolat részleges vagy teljes újradefiniálását vetíti előre.

A helyi társadalom értelmezésében az oktatás-nevelés és az extracurriculáris tevékenység a funkciók, a mentalitás, az értékelés szintjén is párhuzamos tevékenységek, és egymástól nagyon eltérő értékkel bírnak. Az extracurriculáris tevékenység a helyi társadalom szemében hangsúlyosan csak komplementer, szabadidős, kikapcsolódási jellegü program, „nem igazi”, „nem fontos”, nem az iskolai funkció része. Az ilyen jellegű iskolai tevékenységek köre az utóbbi egy-két évtizedben nagyon kibővült. Jellegzetes példái a testvértelepülésekkel kialakított és a családokat is bevonó kapcsolatok, a családokat is nagymértékben mozgósító rendezvények, az iskola felújításában való szülői részvétel, háttéralapítványok létrehozása és forrásbevonási kísérletek sorozata, valamint az iskolához kapcsolható lokális jellegü ünnepek felértékelődése. Ezeket az új típusú tevékenységeket a lokális társadalmi értelmezés és értékelés leválasztja az iskoláról, olyan plusz funkcióként definiálja, ami nem tartozik szorosan az iskolához, és ez a funkcionális leválasztás értékbeli lefokozással is jár.

A vidéki társadalom a pedagógus szakmai kompetenciáinak hasznosítását az oktatási keretre korlátozza. Többféle oka van annak, hogy a vidéki iskolákban ma a pedagógusok szakmai tudásának és személyi képességeinek csupán töredéke hasznosul. Az alacsony tanulólétszám kisebb esélyt kínál arra, hogy egy-egy osztályban olyan tanulócsoport alakuljon ki, amely az adott tárgyból jól teljesít, és a pedagógust nagyobb szakmai teljesítményre ösztönzi. Előfordul, hogy a pedagógus a képzettségének meg nem felelő tárgyakat oktat, de ilyen ok lehet a didaktikai eszközök vagy a müszaki felszereltség hiánya is. Nem utolsósorban pedig kis létszámú vidéki iskolákban sok esetben csökken a teljesítményelvárás is. A pedagógusok szakmai kompetenciáinak tanórán kívüli hasznositására azonban a lokális társadalom nem nyitott. Az ezen a téren tapasztalható korlátok alapvetően mentális jellegüek. Szokatlan, idegen az a gondolat, hogy ennek a tudásnak, kompetenciának és tevékenységnek szolgáltatásjellege és piaci értéke lehet, s hogy a rendelkezésre álló kompetenciakészlet helyi fejlesztéspolitikai potenciált is jelenthetne ezekben a lokális közegekben. 
A helyi vezetés (önkormányzat) és az iskola/oktatás viszonyát nagyon erős aszimmetria jellemzi, és a helyi társadalom véleménye/magatartása ezt az aszimmetriát visszaigazolja. Az aszimmetria lényegét az határozza meg, hogy a vezetők nem tekintik igazán helyi intézménynek az iskolát, ami számukra azt jelenti, hogy nem a helyi vezetők irányítják. A helyi fejlesztési stratégiákban az iskola csak épületként, oktatói állományként és tanulói létszámként, nem pedig a település többi elemével összefüggő lokális tevékenységként jelenik meg. Fejlesztési feladatként pedig csak annyiban, hogy az épületet fel kell újítani. Az aszimmetria kifejeződik a távolságtartás formáiban, az elvárások/utasítások megjelenítésében, illetve az együttműködési alkalmak kezelési módjában egyaránt. Az aszimmetria (a helyi vezetés/adminisztratív intézmény fölényhelyzete és az iskola alárendelt helyzete) a vidéki lokális társadalom egyik meghatározó strukturális jellemzője. Sok esetben hasonló viszony tapasztalható a helyi egészségügyi intézménnyel kapcsolatban is, illetve általában az olyan intézményekkel vagy szakmai szereplőkkel szemben is, amelyek/akik településen kívüli intézményi autoritáshoz tartoznak.

Sajátos, a vidéki társadalom müködésébe integrálódó szerepet alakítanak ki és gyakorolnak a vidéki iskolák vezetői. Ennek alapját az intézményi struktúrák és az ezekben működtetett vezetői szerepek közti viszonynak olyan modellje alkotja, amelyet Romániában az 1989-es rendszerváltás előtti időszak társadalmi környezete termelt ki és erősített meg. Miközben a müködési szabályok, a hivatalos elvárások és intézményi értékelések köre egységes, országos léptékben erőteljesen centralizált, az intézmény helyi működésére és társadalmi szerepére vonatkozó értelmezések és attitüdök világa sok esetben helyi, egyedi, sajátos lehet. A szigorúan szabályozott (a szereplők megítélése szerint indokolatlanul túlszabályozott) struktúrához való igazodás nem zárja ki az ebben a struktúrában vállalt vezetői szerep és magatartás nagyon hangsúlyos egyediesítését, a rendhez való igazodásnak és az egyediesítésnek a helyzetektől függő váltogatását sem (,átjárási technikák", lásd Bodó 1998). A vidéki környezetben két tényező is támogatja ennek a kettősségnek a kialakulását. Az egyik az a tény, hogy az előírások és elvárások jó részének a vidéki iskola a gyakorlatban nem tud megfelelni (legfeljebb formálisan, a hivatalos jelentések és szereplések szintjén). Ezzel szemben a kialakult helyi müködési modell implicit legitimitással rendelkezik, következésképpen azok a lokális értelmezések, magatartások és víziók is elfogadottak, amelyeket a helyi szereplők alakítanak ki, tartanak fenn a helyi iskola működéséről és társadalmi funkciójáról. Másfelől az iskola helyi sajátos müködésére és társadalmi szerepére vonatkozó értelmezések és attitűdök egyediesítését a kisebbségi helyzet is támogatja. Ez tulajdonképpen a „népszolgálat” paradigma (Lőrincz 2015) újraéledésének a következménye. A népszolgálati paradigma mai változatai az elvégzett munka tartalmától, minőségétől, eredményességétől függetlenül is „értékesként”, kiemelt személyes feladatvállalásként tételezik az intézményvezetői munkát. A kisebbség érdekében végzett munka szabad teret ad az intézmény működésére irá- 
nyuló személyes interpretációknak, az intézmény és annak működése összekapcsolódik a személyiséggel, bizonyos értelemben annak részévé, tulajdonává válik. Ezért minden olyan változtatási kezdeményezés, amely az iskola helyi müködésének és társadalmi szerepének megváltoztatásra irányul, egyben „támadást” jelent az intézményvezető személy identitása, habitusa ellen. A vezető személyét (habitusát, identitását) a helyi társadalom védi és visszaigazolja.

\section{Összefoglalás}

Tanulmányunkban korábbi kutatási eredményeink és az intézetünk - a csíkszeredai székhelyű Regionális és Antropológiai Kutatások Központja - keretében végzett újabb térségi elemzések alapján azzal a kérdéssel foglalkoztunk, hogy a székelyföldi vidéki térség társadalmának jellemzői befolyásolják-e a térségi oktatás alakulását. Kutatási tapasztalataink szerint a vidéki térség társadalomtörténeti jellemzői napjainkban is meghatározzák az oktatást, és ez a hatás az intézmények, az intézményvezetői és pedagógusszerepek, a helyi elitszerepek és a lakossági (családi) szerepek terén is megmutatkozik. Összegzésként három következtetést kívánunk kiemelni.

Tapasztalataink szerint a vidéki térségben az oktatás kettős erőtérben formálódik. Egyfelől az országos jogi, intézményi keret és oktatáspolitika, másfelől pedig a térségi társadalom működési modellje alakítja a mindennapi oktatási gyakorlatot. Maga a térségi oktatás e két tényezőcsoport interferenciája eredményeként válik olyanná, amilyennek ma látjuk.

A székelyföldi térségben is működő, romániai magyar kisebbségi oktatásra irányuló normatív diskurzus mindkét tényezőcsoport hatását elfedi. Az országos rendszer hatásából gyakorlatilag csak a kisebbségre nézve hátrányos hatásokat, a térségi oktatás működéséből pedig a kisebbségi oktatási jogérvényesítéssel kapcsolatos hiányokat és igényeket emeli ki. A normatív diskurzus éppúgy nem foglalkozik a térségi társadalom hatásával, ahogy a két tényezőcsoport (országos rendszer, térségi társadalom) interferenciájával sem.

A vidéki oktatási intézmények újrapozicionálásával kapcsolatos elemzéseink alapján úgy véljük, hogy fejlesztéspolitikai megfontolásokból - amennyiben sor kerülne olyan program kidolgozására, amely a rurális iskolák működésének tényleges helyzetfeltárását, illetve az oktatási intézmények lokális szerepeinek újrapozicionálását célozza - figyelembe kell venni a térségi társadalom hatásának elemzését is. Az oktatáskutatás ebben a térségben a vidékkutatás részeként kezelhető. Egy ilyen szakmai lépés természetesen azt is jelenti, hogy a kutatásnak - amennyiben eredményeivel támogatni kívánja a kisebbségi oktatást - ki kell lépnie a normatív szemléleti és diszkurzív keretből. A tanulmányban jelzett kutatási tapasztalatok kiindulópontokat kínálhatnak egy ilyen térségi léptékü szakmai fordulat számára. 


\section{Jegyzet}

1 A témával kapcsolatos összefoglaló anyag és az online olvasható linktár az Intézet honlapján érhető el: http://www.kamintezet.ro/?q=node/95

\section{Irodalom}

Almstedt, A., Brouder, P., Karlsson, S., Lundmark, L. (2014): Beyond post-productivism: from rural policy discourse to rural diversity. European Countryside, 4., 297-306. https://doi.org/10.2478/ euco-2014-0016

Bæck, U. D. K. (2015): Rural Location and Academic Success-Remarks on Research, Contextualisation and Methodology. Scandinavian Journal of Educational Research, 4., 435-448. https://doi.org/ 10.1080/00313831.2015.1024163

Barna G., Kapitány B., Kiss T., Márton J., Toró T. (2016): Iskolák veszélyben. Tanulmányok a Székelyföldön kívüli magyar oktatás helyzetéról. Nemzeti Kisebbségkutató Intézet, Kolozsvár

Bauch, P.A. (2001): School-Community Partnerships in Rural Schools: Leadership, Renewal, and a Sense of Place. Peabody Journal of Education, 2., 204-221. https://doi.org/10.1207/S15327930pje7602_9

Biró Z. (1984): Beszéd és környezet. Kriterion Kiadó, Bukarest

Biró A. Z. (2016): A fiatal gazdák innovációs szerepe a székelyföldi térségben. In: Biró A. Z., Magyar F. (szerk.): Agrárinnováció - térségi esély. Fiatal gazdák a székelyföldi térségben. Státus Kiadó, Csíkszereda, $13-56$.

Biró A. Z., Bodó J., Gagyi J., Túros E. (1994): A túlélés vonzásában. Helyzetelemző tanulmány a romániai magyar oktatási/nevelési szerkezetről. In: Túros E.(szerk.) Változásban? Elemzések a romániai magyar társadalomról. Pro-Print Kiadó, Csíkszereda, 67-92.

Biró A. Z., Bodó J. (szerk.) (2016): Internet - Iskola - Anyanyelv. Státus Kiadó, Csíkszereda

Biró A. Z., Bodó J., Burus-Siklódi B. (szerk.) (2015): Szakképzés, Együttmüködés, Társadalmi modernizáció. Alutus Kiadó, Csíkszereda

Biró A. Z., Laczkó-Albert E., Sárosi-Blága Á. (szerk) (2019): Beruházás és/vagy közösségépités. A helyi fejlesztés mintázatai Gyergyóremetén. Gyergyóremete helyi önkormányzata, F\&F International

Biró A. Z., Magyar F. (szerk.) (2017): A generációváltás esélyei. Agrárvállalkozók innovatív szerepe a székelyföldi térségben. Státus Kiadó, Csíkszereda

Biró A. Z., Ozsváth-Berényi H. (szerk.) (2010): Hogyan tovább, közoktatás? Hargita Népe Kiadó, Csíkszereda

Biró A. Z., Sárosi-Blága Á. (2018): Rurális iskolák - válaszút előtt? Pro Scientia Ruralis, 3-4.,105-147.

Bodó J. (1998): Átjárási technikák a szocializmusban a társadalom privát és hivatalos szférája között. In: Bodó J.. (szerk): Fényes tegnapunk. Tanulmányok a szocializmus korszakáról. Pro-Print Kiadó, Csíkszereda, 31-80.

Bodó, J. (szerk.) (2004): ALMa - Acces to the Labour Market. Alutus Kiadó, Csíkszereda

Bodó J. (szerk.) (2019): Vidék és Társadalom. DOMUS csoportos kutatási programok. KAM - Regionális és Antropológiai Kutatások Központja, Státus Kiadó, Csíkszereda

Chesire, L., Meurk, C., Woods, M. (2013): Decoupling farm, farming and place: Recombinant attachments of globally engaged family farmers. Journal of Rural Studies, 30., 64-74. https://doi.org/10.1016/ j.jrurstud.2012.11.005

Corbett, M., Helmer, M. (2017): Contested geographies: competing constructions of community and efficiency in small school debates: Contested geographies. Geographical Research, 1., 4-57. https://doi.org/10.1111/1745-5871.12209

G. Fekete É. (1999): Bevezetés az alulról vezérelt (bottom-up) vidékfejlesztés elméletébe és módszertanába. PHARE- Kereskedelmi és Vendéglátóipari Főiskola, Szolnok 
G. Fekete É. (2001): Együtt! De hogyan? A kistérségi fejlesztő szervezetek megjelenése a területfejlesztésben. MTA RKK, Pécs, Miskolc

G. Fekete É. (2008): A fejlődés és versenyképesség értelmezése kevésbé fejlett térségekben. In: Lengyel I., Lukovics M. (szerk.): Kérdőjelek a régiók gazdasági fejlődésében. JATEPress, Szeged, 130-152.

Gray, I., Sinclair, P. (2005): Local Leaders in a Global Setting: Dependency and Resistance in Regional New South Wales and Newfoundland. Sociologia Ruralis, 1-2., 37-52. https://doi.org/10.1111/j. 1467-9523.2005.00289.x

Herslund, L. (2012): The rural creative class: Counterurbanisations and entrepreneurship in the Danish countryside. Sociologia Ruralis, 52., 235-255. https://doi.org/10.1111/j.1467-9523.2011.00560.x

Lingam, G., Lingam, N., Raghuwaiya, K. (2014): Challenges for Rural School Leaders in a Developing Context: The Case of Solomon Islands. International Journal of Humanities and Social Sciences, 2., 372-380.

Lőrincz D. J. (2015): A népszolgálat. In: Bárdi N., Filep T. G., Lőrincz D.J. (szerk): A közösségi elkötelezettség alakváltozatai a magyar kisebbségek körében. Kalligram Kiadó, Pozsony, 288-322.

Lundmark, L. (2006): Restructuring and employment change in spearsely populated areas: Examples in northern Sweden and Finland. DSEG, Umea University, Sweden

Lyson, T. (2002): What does a school mean to a community? Assessing the social and economic benefits of schools to rural villages in New York. Journal of Research in Rural Education, 3., 131-137.

Mandel K. (2016): Kihívások. Középpontban a székelyföldi oktatás kérdései. Gondolat Kiadó, Budapest

Mather, A. S., Hill,G., Nijnik, M. (2006): Post-productivism and rural land use: Cul de sac or challenge for theorization? Journal of Rural Studies, 22., 441-455. https://doi.org/10.1016/j.jrurstud. 2006.01.004

McCracken, J. D., Miller, C. (1988): Rural Teachers' Perceptions of Their Schools and Communities. Research in Rural Education, 5., 2. 23-26.

Miller, C., Bruce, M. (1995): The Role of Rural Schools in Community Development: Policy Issues and Implications. Journal of Research in Rural Education, 3., 163-172.

OECD [Organisation for Economic Co-operation and Development] (2006): The new rural paradigm: Policies and governance. OECD publications, Paris https://www.ircwash.org/sites/default/files/ OECD-2006-New.pdf (Letöltés ideje: 2020.05.16.)

Ray, C. (1998): Culture, intellectual property and territorial rural development. Sociologia Ruralis, 38., 3-20. https://doi.org/10.1111/1467-9523.00060

Roberts, P. (2013): The role of an authentic curriculum and pedagogy for rural schools and the professional satisfaction of rural teachers. Australian and International Journal of Rural Education, 2., 89-99.

Rostás Z. (szerk.) (1989): „Hát idefigyelj, édes fiam”. Albatrosz Kiadó, Bukarest

Túros E. (szerk.) (2005): Igény a tanulásra. Pro-Print Kiadó, Csíkszereda

Túros E. (2006): Szakmai szintézis a székelyföldi térség oktatási intézményrendszerével és változási folyamataival kapcsolatos kutatási programok és szakmai publikációk alapján. Kézirat, KAM - Regionális és Antropológiai Kutatások Központja, Adattár

Van der Ploeg, J. D., Renting, H., Brunori, G., Knickel, K., Mannion, J., Marsden, T., Ventura, F. (2000): Rural development: from practices and policies towards theory. Sociologia Ruralis, 40., 391-408. https://doi.org/10.1111/1467-9523.00156

Wallin, D. C., Newton, P. (2014): Teaching Principals in Small Rural Schools: "My Cup Overfloweth". Alberta Journal of Educational Research, 4., 708-725.

Williams, D. T. (2010): The Rural Solution. How Community Schools Can Reinvigorate Rural Education. Center for American Progress

Woods, M. (2007): Engaging the global countryside: globalization, hybridity and the reconstitution of rural place. Progress in Human Geography, 31., 485-507. https://doi.org/10.1177/0309132507079503 